長時間の側臥位にて下肢コンパートメント症候群をきたした 1 例

\author{
武田＼cjkstart裕介, 䒩田 泰治, 平良 彰浩 \\ 篠原 伸二, 黒田 耕志, 田中 文啓
}

\begin{abstract}
要 旨
今回我々は左側臥位手術後に下肢コンパートメント症候群を発症した一例を経験したので報告する.

症例は 84 歳男性. 既往歴は両下肢重症閉塞性動脈硬化症. 右下葉肺癌に対して左側臥位で開胸右下葉切除を行った. 術中 に血圧低下, 酸素化低下を認め, 一旦閉創のうえ仰臥位に戻し, 状態が改善したために再度左側卧位とし右下葉切除を行っ た. 術後 1 日目に右下肢の疼痛, 腫脹を認め, 右下肢コンパートメント症候群の診断で, 減張切開術を行った. 術後のコン パートメント症候群は砕石位や頭低位での報告が多いが，呼吸器外科領域，側臥位での報告はほとんどない，本症例を踏ま えた発症リスクや予防策について文献的考察を含め報告する.
\end{abstract}

索引用語：コンパートメント症候群，側臥位

compartment syndrome, lateral decubitus position

はじめに

コンパートメント症候群は外傷後に生じる疾患として 広く知られているが, 手術における合併症としても起こ りうる疾患である. 術後のコンパートメント症候群は砕 石位や頭低位での報告が多いとされる。しかし, 呼吸器 外科領域・側臥位での発症例は報告例がほとんどない。 今回我々は左側臥位手術後に下肢コンパートメント症候 群を発症した一例を経験し, 文献的考察を加えて報告す る.

\section{症例}

84 歳. 男性. 身長 $157 \mathrm{~cm}$, 体重 $60 \mathrm{~kg}$, BMI 24.2 .

主 訴: 下肢痛.

既往歴：72 歳咽頭癌手術.

79 歳直腸癌内視鏡的切除後.

79 歳閉塞性動脈硬化症手術 (大腿動脈一大腿動脈バイ パス術).

産業医科大学第 2 外科

原稿受付 2020年 2 月 8 日

原稿採択 2020年 3 月 5 日
その他高血圧症.

内 服: シロスタゾール $50 \mathrm{mg}$, イコサペント酸エチ ル $900 \mathrm{mg}$.

喫煙歴：Ex-smoker：30 本/日 ×54 年.

家族歴：特記すべき事項なし.

現病歴：閉塞性動脈硬化症に対してシロスタゾール， イコサペント酸エチル内服中であったため, 術前 1 週間 前に上記 2 剤を中止とし, 周術期にはヘパリンブリッジ を行った。閉塞性動脈硬化症に関しては, 間欠性跛行を 認め, ABI（Ankle Brachial Pressure Index）検査では 右：0.26, 左：0.3であった。 さらにCTA(CTAngiography)では右外腸骨動脈の閉塞を指摘され, 間欠性跛行の 症状増悪も認めていたため, 手術予定であった。

右下葉肺癌に対して左側臥位で開胸右下葉切除術を施 行．術中に挿管チューブ固定不良による換気不良が原因 で低酸素血症をきたし，1時間程度の血圧低下を認めた。 仰臥位への体位変換を行ったが, 抻管チューブの再固定 を行い, 酸素化や血行動態が改善したため, 左側臥位と し手術を完遂した。この時, 心エコーを行ったが明らか な異常所見は指摘されなかった. 術時間 5 時間 37 分, 麻 酔時間 9 時間 17 分, 出血は $570 \mathrm{~mL}$ であった。術当日よ り右下肢に経度腫脹と疼痛を認めた。術後 1 日目早朝に 


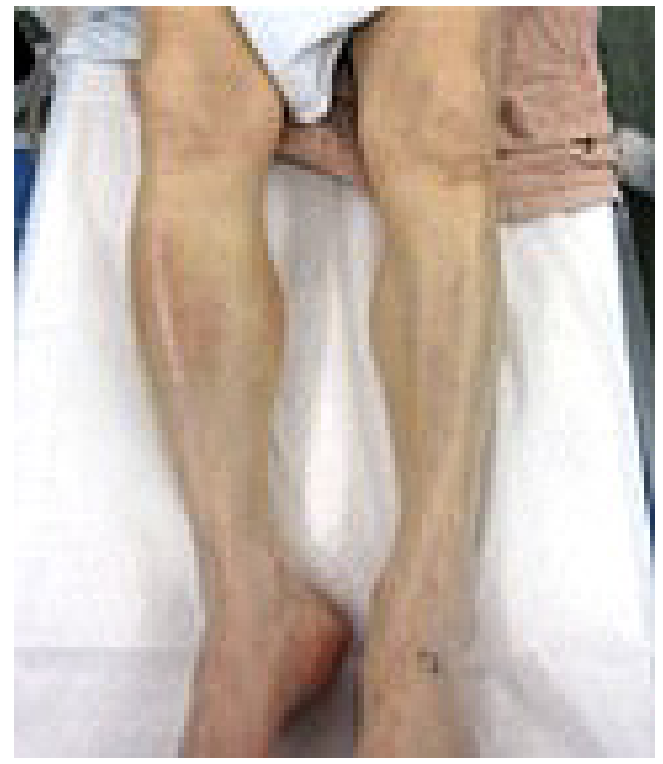

Fig. 1 Swollen right lower limb on the first post-operative day.

右下肢の疼痛・腫脤の増悪を認めた。なお，弾性ストッ キングとフットポンプは術中, 術後 1 日目まで着用して いた。

身体所見：右下腿腓腹部に腫脹と発赤を認めた（Fig. 1). 深部静脈血栓症を疑い下肢エコー超音波検查を施行 したが, 媣部静脈血栓症および急性動脈閉塞は否定的で あった. needle manometer 法を施行したところ、コン パートメント内圧は 4 区画で前方 : $20 \mathrm{mmHg}$, 側方 : 18 $\mathrm{mmHg}$, 浅後方 : $18 \mathrm{mmHg}$, 深後方 : $43 \mathrm{mmHg}$ (正常内 圧 0 〜 $\mathrm{mmHg}^{\mathrm{l})}$ ）と上昇を認めた。

血液生化学所見：CK（正常值 59〜248 IU/L）は 18486 $\mathrm{IU} / \mathrm{L}$ と著明に上昇しており，同日に再検すると 23372 IU/L まで上昇を認めた。 また, D ダイマー(正常值 0.0 $1.0 \mu \mathrm{g} / \mathrm{mL}$ ) は $14.4 \mu \mathrm{g} / \mathrm{mL}$, LDH（正常值 124〜222 IU/ L）は $735 \mathrm{IU} / \mathrm{L}$ と上昇を認めた。

経 過：下肢コンパートメント症候群の診断となり， 肺癌術後 1 日目に筋膜減張切開術を施行した。その後は 症状は改善し, 陰圧閉鎖療法を行い, 筋膜減張切開術 7 日後に切開創の閉創を行った (Fig. 2). CK は徐々に低下 し，正常值まで改善を認めた.

\section{考察}

呼吸器外科領域, 側臥位での下肢コンパートメント症 候群の報告は我々の調べた限りではほとんどみられず,
呼吸器外医には馴染みの少ない合併症である.

コンパートメント症候群の所見は 6P(Pain, Pressure,

Paresis, Paresthesia, Pulse presence, Pink color) とい われる. 血液検查では $\mathrm{CK}, \mathrm{LDH}$ 等の上昇が認められる. 画像検查としては下肢造影 CT, MRIT2 強調画像が有用 とされている21. 治療としてはしばしば筋膜減張切開が行 われるが, 適応としては様々な報告があるが，内藤ら ${ }^{31}$ は コンパートメント压 $30 \mathrm{mmHg}$ 以上を適応としている. 横紋筋融解症に伴う急性腎不全への対応も必要となる ${ }^{1)}$. 早急な治療が必要となり，6時間以内の治療介入でほほ 全快が見込め, 12 時間以内であれば永久的な後遺症は回 避できるとされる

術中の体位が原因で健常な足に生じたコンパートメン 卜症候群は Well leg compartment syndrome (WLCS) と 呼ばれ，早急な診断と治療が行われなければ，不可逆的 な筋・神経障害をきたす，筋区画内組織の血流障害によ る組織虚血が原因で発症すると言われている。発症機序 としては虚血により毛細血管内皮が損傷し, 炎症性メ ディエーターの遊走により細胞障害を生じ，内圧上昇を きたすことや，虚血となった筋組織の圧迫解除後に虚血 再灌流障害を生じ，内圧上昇をきたすこととされてい

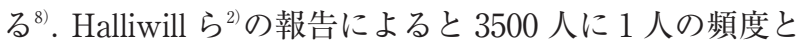
報告されており，砕石位が最も多いと言われている. Simms ら9)によれば WLCS65 例中，4 例の死亡, 11 例の 下肢切断が必要であったと報告しており, WLCS は極め て重篤な合併症と考えられる。WLCSのリスクファク ターとしては手術体位（砕石位，頭低位)，手術時間（4 時間以上), 低血圧, 低体温, 脱水, 出血量, 動脈硬化症, 肥満, 弾性ストッキング, 間欠的空気圧迫法などが挙げ

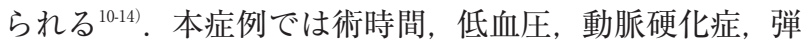
性ストッキング，間欠的空気圧迫法が当てはまった，本 症例の合併症の原因として最も考えやすいのが，患肢へ の血流低下である．患肢の閉塞性動脈硬化病変が血行再 建時よりも進行しており，潜在的な患肢の血流不良が存 在していた可能性がある。そのうえ，術中の換気不良に 伴う低酸素血症や低血圧が患肢の虚血を増悪させた可能 性がある。また，手術時の下肢屈曲位・側臥位がさらな る血流低下の要因になった可能性も考えられる. 次に, 手術は左側臥位で行っており，患肢である右下肢は上方 であり，下方と比べ血流が低下していた可能性も考えら れる。術前の下肢動脈ドップラーでは両側足背動脈の聴 診は可能であったが術中は評価できなかった，下肢動脈 

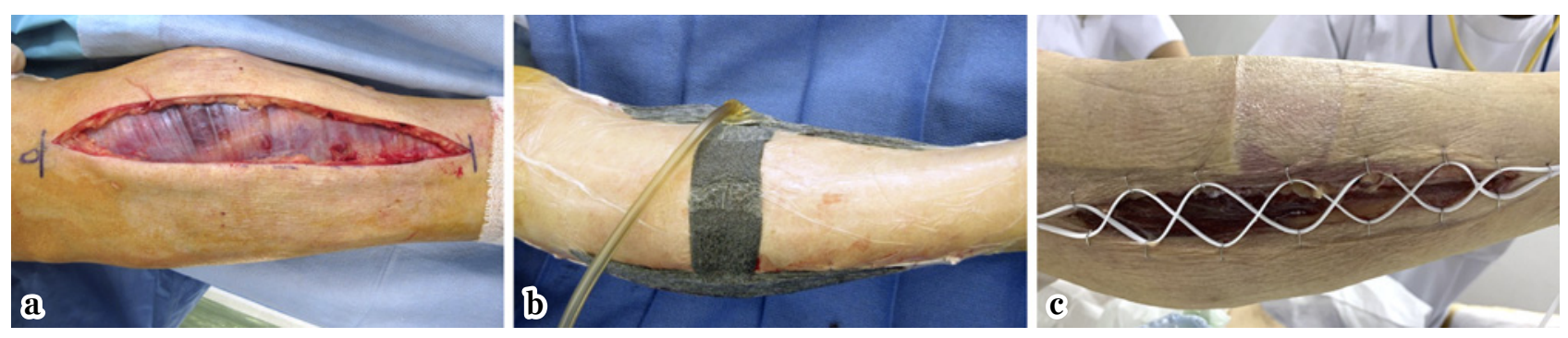

Fig. 2 Progress after the operation of decompressive fasciotomy.

a: Surgical decompression

b: Negative pressure wound therapy

c: Wound closure

血流低下による阻血状態を早期発見するためには足背動 脈の触診や下肢動脈ドップラーでの評価が必要であった と考えられる.また, 体位変換ごとに足背動脈などの拍 動のチェックは行えておらず体位変換の際, 一時的に右 下肢が阻血状態になった可能性もある.

今後は, 側臥位の手術であっても本症例のように下肢 血流が低下する恐れのある症例では, 術中の下肢動脈 ドップラーでの血流評価や, 閉塞性動脈硬化などの下肢 動脈狭窄を認める症例では下肢の圧迫を避けるために弾 性ストッキングや間欠的空気圧迫法の着用を避ける等の 対策が必要と考えられた。ただし, 間欠的空気圧迫法に 関しては, 使用した方が, 下肢コンパートメント圧が減

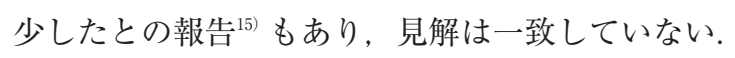

側臥位の手術でも今回のように合併症や術中イベント によってはWLCSが起こりうる可能性を念頭におかな ければならない。

\section{結語}

側臥位手術後の下肢コンパートメント症候群の症例を 経験した. 側臥位手術でも WLCSが起こりうることは念 頭に置かなければならない.

\section{利益相反}

本論文について申告する利益相反はない.

\section{文献}

1. Heppenstall B, Tan V. Well-leg compartment syndrome. Lancet 1999; 354: 970.

2. Halliwill JR, Hewitt SA, Joyner MJ, Warner MA. Effect of various lithotomy positions on lower-extremity blood pressure. Anesthesiology 1998; 89: 1373-6.

3. 内藤正俊, 緒方公介, 泊 真二, 森山正明. 急性型 Compartment 症候群. 別冊整形外 1986; 10: 116-21.

4. Bauer EC, Koch N, Janni W, Bender HG, Fleisch MC. Compartment syndrome after gynecologic operations: evidence from case reports and reviews. Eur J Obstet Gynecol Reprod Biol 2014; 173: 7-12.

5. Boesgaard-Kjer DH, Boesgaard-Kjer D, Kjer JJ. Well-leg compartment syndrome after gynecological laparoscopic surgery. Acta Obstet Gynecol Scand 2013; 92: 598600.

6. Elliott KG, Johnstone AJ. Diagnosing acute compartment syndrome. J Bone Joint Surg Br 2003; 85: 625-32.

7. Matsen FA 3rd, Clawson DK. The deep posterior compartmental syndrome of the leg. J Bone Joint Surg Am 1975; 57: 34-9.

8. Chase J, Harford F, Pinzur MS, Zussman M. Intraoperative lower extremity compartment pressures in lithotomy-positioned patients. Dis Colon Rectum 2000; 43: $678-80$.

9. Simms MS, Terry TR. Well leg compartment syndrome after pelvic and perineal surgery in the lithotomy position. Postgrad Med J 2005; 81: 534-6.

10. 福元智子, 野田祐紀子, 安田哲二郎, 児玉謙次, 高橋成輔. 
術後下肢コンパートメント症候群をきたした症例の疼痛

治療. 臨麻 2008; 32: 1635-9.

11. Hauser J, Lehnhardt M, Steinau HU, Homann HH. Trocar injury of the retroperitoneal vessels followed by lifethreatening postischemic compartment syndrome of both lower extremities. Surg Laparosc Endosc Percutan Tech 2008; 18: 222-4.

12. Lachmann EA, Rook JL, Tunkel R, Nagler W. Complications associated with intermittent pneumatic compression. Arch Phys Med Rehabil 1992; 73: 482-5.
13. Martin JT. Compartment syndromes: concepts and perspectives for the anesthesiologist. Anesth Analg 1992; 75: $275-83$.

14. Verdolin MH, Toth AS, Schroeder R. Bilateral lower extremity compartment syndromes following prolonged surgery in the low lithotomy position with serial compression stockings. Anesthesiology 2000; 92: 1189-91.

15. Pfeffer SD, Halliwill JR, Warner MA. Effects of lithotomy position and external compression on lower leg muscle compartment pressure. Anesthesiology 2001; 95: 632-6.

\title{
A case of well leg compartment syndrome after prolonged lateral decubitus position
}

\author{
Yusuke Takeda, Taiji Kuwata, Akihiro Taira \\ Shinji Shinohara, Koji Kuroda, Fumihiro Tanaka
}

Department of Second Surgery, School of Medicine, University of Occupational and Environmental Health, Japan

An 84-year-old male patient with severe arteriosclerosis obliterans of both lower extremities developed right leg compartment syndrome after surgery in a lateral decubitus position. In a left lateral decubitus position, he underwent right lower lobectomy on thoracotomy for primary lung cancer. Although, during the operation, we returned him to a supine position, hypotension and hypoxia were observed. From the first post-operative day, he suffered spontaneous pain and swelling of the right lower leg. We diagnosed him with compartment syndrome, and performed fasciotomy on the same day.

Even when we perform operations in a lateral decubitus position for a long period, patients should be managed while keeping the risk of compartment syndrome in mind. 